\title{
A duplicação de trabalhos científicos
}

Questões relativas à ética na publicação científica têm recebido continuada reflexão por parte do Conselho Editorial de Cadernos de Saúde Pública (CSP). Em editoriais anteriores debruçamo-nos sobre a questão da múltipla autoria, cuja legitimidade, em muitos casos, tem sido questionada (vol. 9, p.115) e do plágio (vol. 12, p.440), delito gravíssimo que, em muitos países, é motivo de aplicação de severas penalidades. Estes dois temas têm gerado amplo debate, que se faz presente nas seções de cartas e em editoriais de importantes periódicos nas áreas da saúde e ciências biomédicas 1,2 .

Neste editorial abordamos um outro tópico relativo à ética na publicação científica, qual seja, o problema da duplicação de trabal hos. Nossa escolha deveu-se, em primeiro lugar, por se tratar de tema atual de debate por parte da comunidade internacional de editores científicos3,4,5. Em segundo lugar, por estarmos nos deparando com um número crescente de textos supostamente originais submetidos para publicação em CSP e que, por ocasião de sua avaliação por parte dos consultores, ou mais tardiamente, quando o autor recebe com o termo de cessão de direitos autorais de seu trabalho, vem à tona que o mesmo foi anteriormente publicado em outro veículo.

A publicação duplicada ou fragmentada é considerada séria infração de ordem ética a ponto de, no mês passado, ter sido objeto de uma oficina de trabal ho organizada pelo European Association of Science Editors, realizada na Inglaterra. A duplicação de artigos é definida como a publicação de um mesmo trabalho, fruto de uma mesma pesquisa, em distintos periódicos. A alegação de que os "públicos" são diferentes, daí porque republicar em revistas de diferentes áreas, países ou mesmo em línguas distintas, não se justifica. Falta também grave é a fragmentação dos resultados de uma pesquisa, isto é, sua dispersão através de vários "pequenos" artigos com o intuito de "aumentar" a produção de um determinado pesquisador ou grupo de investigadores.

A prática de publicação duplicada e/ ou fragmentada gera inúmeros prejuízos ao sistema de revistas científicas. Isto porque não apenas consultores são mobilizados inutilmente mas, muitas vezes, chega-se mesmo a pagar revisão e diagramação para somente então, ao receber as provas, o autor eventual mente informar que o trabalho foi publicado anteriormente. Isto apesar de estar explícito nas instruções para os autores da maioria dos periódicos que o texto submetido deve ser obrigatoriamente original. Gera-se também inútil sobrecarga das bases de informação bibliográfica com textos de igual conteúdo, porém publicados sob títulos e idiomas distintos, ordem dos autores alterada, e em revistas ou mesmo em países diferentes. Vale ressaltar que o sistema adotado por grande parte das agências de fomento à pesquisa e mesmo a academia, particularmente no que se refere aos sistemas de promoção, podem estar estimulando tais práticas ao enfatizar mais a "quantidade" do que a "qualidade" da produção científica.

É necessário que a comunidade científica em sua totalidade, incluindo editores, consultores, autores e leitores, atente para esta problemática. Esta discussão deve ser estimulada nos vários espaços acadêmicos, em particular nos cursos de pós-graduação, aonde acontece a formação de novos pesquisadores. As instituições, por sua vez, necessitam desenvolver mecanismos mais sensíveis para avaliar a produção científica, que preferencialmente devem envolver tanto aspectos qual itativos como quantitativos no reconhecimento do mérito de pesquisadores.

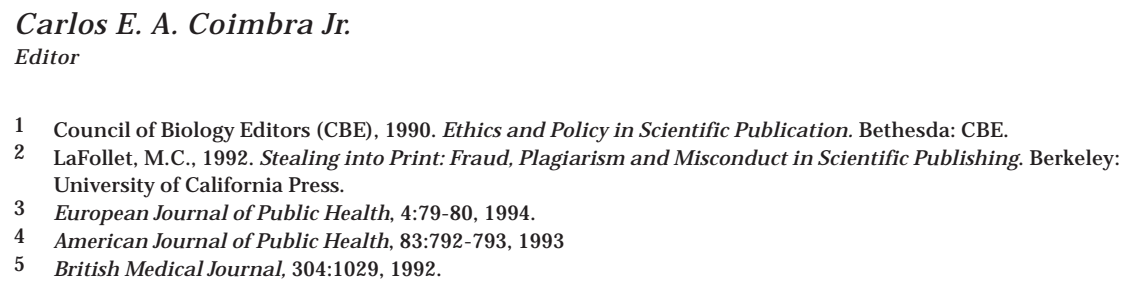




\section{Duplication of Scientific Articles}

Ethical issues in scientific publication have been a source of ongoing concern for the Editorial Board of Cadernos de SaúdePública (Reports in Public Health). Previous editorials have dwelt on the issue of multiple authorship, the legitimacy of which has been questioned in many cases (vol.9, p.115) and plagiarism (vol. 12, p. 440), a grave offense which in many countries is severely punished. The two themes have fueled a broad debate, as expressed in both letters to editors and editorials by major journals, including several from the area of health and biomedical sciences 1,2 .

Today's editorial deals with another issue pertaining to ethics and scientific publication, namely duplication of scientific work. Our choice stemmed first from the fact that this is a current point of debate among the international community of scientific editors $3,4,5$. Second, because a growing number of supposedly original articles have been submitted for publication by Cadernos de Saúde Pública which, upon assessment by reviewers, or even later, when the time comes for authors to sign a copyright waiver on their work, turn out to have been published previously in other periodicals.

Duplicate or fragmented publication is considered a serious breach of ethics, to the point of becoming the focus of a workshop organized last month in Great Britain by the European Association of Science Editors. Duplication of articles is defined as publishing the same article, resulting from the same research, in different periodicals. The claim that the "reader publics" are different, and that one can thus publish the same material in different areas, countries, or even languages, is unjustifiable. Another serious offense is fragmentation of research, i.e., spreading the results out among various "small" articles in order to "increase" production by a given researcher or group of investigators.

The practice of duplicate or fragmented publication harms the scientific journal system in numerous ways. Consultants are mobilized pointlessly. Worse yet, in many cases, reviewing, editing, and graphic layout services are paid for, and only then does the author advise the journal that the article has al ready been published elsewhere, despite the fact that instructions to authors in most journals explicitly require that only original papers may be submitted. In addition, bibliographical data bases are needlessly overloaded with articles containing identical information, albeit published under different titles, in different languages, with the order of the authors changed, in different journals, or even in different countries. The system adopted by many research funding agencies and even the academic community, especially in relation to career promotion, may well be stimulating such practices when it emphasizes "quantity" over "quality" of scientific production.

The scientific community as a whole, including editors, consultants, authors, and readers, needs to be aware of this problem. Discussion should be encouraged in the various academic spheres, particularly in graduate courses, where new researchers are being trained. Institutions must develop more sensitive mechanisms to assess scientific production, which would preferably involve qualitative as well as quantitative aspects in acknowledging the merit of researchers.

Carlos E. A. Coimbra Jr. Editor

Council of Biology Editors, 1990. Ethics and Policy in Scientific Publication. Bethesda: Council of Biology Editors, Inc.

LaFollet, M.C., 1992. Stealing into Print: Fraud, Plagiarism and Misconduct in Scientific Publishing. Berkeley: University of California Press.

European Journal of Public Health, 4:79-80, 1994

4 American Journal of Public Health, 83:792-793, 1993.

5 British Medical Journal, 304:1029, 1992. 